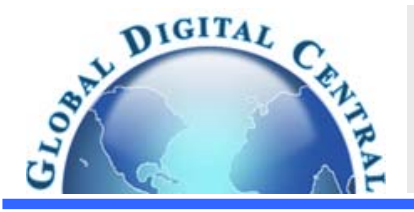

Frontiers in Heat and Mass Transfer

Available at www.ThermalFluidsCentral.org

\title{
COMPUTATIONAL STUDIES OF SWIRL RATIO AND INJECTION TIMING ON ATOMIZATION IN A DIRECT INJECTION DIESEL ENGINE
}

\author{
Renganathan Manimaran ${ }^{\mathrm{a}}$, Rajagopal Thundil Karuppa Raj, ${ }^{\mathrm{b}, *}$ \\ ${ }^{a}$ Thermal and Automotive Research Group, School of Mechanical and Building Sciences, VIT Chennai, Tamilnadu, India \\ ${ }^{b}$ Energy Division, School of Mechanical and Building Sciences, VIT Vellore, Tamilnadu, India
}

\begin{abstract}
Diesel engine combustion modeling presents a challenging task with the formation and breakup of spray into droplets. In this work, 3D-CFD computations are performed to understand the behaviour of spray droplet diameter and temperature during the combustion by varying the swirl ratio and injection timing. After the validation and grid and time independency tests, it is found that increase in swirl ratio from 1.4 to 4.1 results in peak pressure rise of 8 bar and an advancement of injection timing from 6 deg bTDC to 20 deg bTDC results in increase of peak pressure by $15 \%$.

Keywords: Spray droplet parameters, Computational Fluid Dynamics, Combustion, Emissions, 4S-Direct injection diesel engine.
\end{abstract}

\section{INTRODUCTION}

During this decade, the demanding stringent exhaust emission regulations have prompted for innovative spray technologies and better combustion control strategies especially in diesel engines due to $\mathrm{NO}_{\mathrm{x}}$ and particulate emissions. Generally the $\mathrm{NO}_{\mathrm{x}}$ and particulate matter are controlled after the combustion in the exhaust pipeline using catalytic converters. The primary cause for these emissions lies behind the distribution of fuel droplets inside the combustion chamber in ensuring complete combustion. Trade-off between the power output and the $\mathrm{NO}_{\mathrm{x}}$ emissions is better achieved using controlled feedback injection timing (Heywood 1988) mainly in compression ignition engines. The time period between the spray of diesel fuel and actual start of combustion is generally referred as ignition delay period. This ignition delay period is a crucial task during experimental investigation of diesel engines. The study of these processes by experimental approach involves expensive instruments with high level of skill and moreover, consumes a lot of time. Nowadays computational techniques evolved such that modeling these processes can contribute to better understanding of spray penetration, combustion and pollutant formation.

Reitz and Diwakar (1986) implemented an Eulerian-Lagrangian spray and atomization model for diesel sprays. Their numerical study on internal flow characteristics for a multi-hole fuel injector gives better agreement with the available experimental data. This indicates the capability of numerical model for studying diesel spray characteristics. Magnussen and Hjertager (1976) developed a model based on the eddy break-up concept. This model relates the combustion rate to the eddy dissipation rate. This model expresses the rate of reaction by the mean mass fraction of the reacting species, the turbulence kinetic energy and the rate of dissipation.

Hossainpour and Binesh (2009) highlighted the prediction of droplet spray models in a CFD code. The spray calculations are based on statistical method referred as discrete droplet method. The results are validated with the experimental data. They reported that spray penetration which plays a dominant role in combustion and emission characteristics are predicted better with modeling methodologies.
Prasad et al. (2011) carried out simulation on different bowl configuration to analyze the effect of swirl on combustion. They found that re-entrant piston bowl could create highest turbulent kinetic energy and swirl in the cylinder. They also studied the effects of injector sac volume on the combustion and emission. The studies indicate that sacless injector could result in lower emissions. Many literature (Arcoumanis et al. 1997; Rakopoulos et al. 2010; Kar et al. 2012; Torregrosa et al. 2012; Thurnheer et al. 2011) insist that spray dynamics plays a strong role on evaporation rate, flow field, combustion process and emissions. As a result, the atomization of fuel affects the combustion efficiency and pollutant formation. Modeling the atomization process during diesel combustion requires careful validation with the experimental results.

The in-cylinder turbulent motion of air is characterized by swirl, squish and tumble phenomena. Swirl is varied by designing the intake port and shaping the piston bowl for re-entrant combustion. For combustion chamber of re-entrant effects, the turbulent kinetic energy is intensified at TDC of compression stroke due to the conservation of angular momentum. Combustion is efficient and leads to low soot and high $\mathrm{NO}_{\mathrm{x}}$ emissions (Costa et al. 2012; Chmela et al. 2007; Catania et al. 2011; Kondoh et al. 1985). The effect of variation of injection timing in diesel engine was studied by Sayin and Canakci (2009). They found that $\mathrm{NO}_{\mathrm{x}}$ and $\mathrm{CO}_{2}$ emissions increased while the unburned $\mathrm{HC}$ and $\mathrm{CO}$ emissions decreased when injection timing is advanced. Han et al. (1996) investigated numerically the multiple injections and split injection cases. They found that split injection reduces the soot significantly without the change in $\mathrm{NO}_{\mathrm{x}}$ emissions whereas multiple injections reduce $\mathrm{NO}_{\mathrm{x}}$ significantly. The numerical study on diesel engine simulation with respect to injection timing and the air boost pressure was carried out by Jayashankara et al (2010) using commercial CFD code. They validated the results of flow-field from CFD simulation with the experimental work of Payri et al (2004). From the CFD simulation, they observed that increase in cylinder pressure, cylinder temperature and $\mathrm{NO}_{\mathrm{x}}$ emissions results from advancing the injection timing. They also found from simulation that the supercharged and inter-cooled engine results in higher $\mathrm{NO}_{\mathrm{x}}$ emissions as compared to naturally aspirated engines. 
Several experimental and computational studies are performed to understand the spray, combustion and pollutant formation processes. However, the study of droplet parameters towards combustion and emissions are rarely reported in literature (R. Manimaran, R. Thundil Karuppa Raj, 2013). Further, the study related to the behaviour of droplet parameters during combustion on the effect of swirl ratio and injection timing is not explored further in the literature. This paved the way for carrying out a task to study the droplet variables, combustion and emission characteristics by varying the engine parameters. Droplet variables like droplet mass, droplet sauter mean diameter, droplet temperature, droplet velocity and spray penetration can be measured experimentally but leads to a tedious task. To avoid the laborious task by experiments, CFD modeling gives better understanding on the processes to study the droplet variables on the variation of swirl and injection timing. However, the accuracy of the models and schemes employed should be ascertained and the result has to be validated with experimental results. Hence the aim of the present work is to understand the behavior of droplet variables towards the combustion and pollutant formation. The commercial CFD code, STAR-CD is used to simulate the in-cylinder processes such as spray, auto-ignition, combustion and pollutant formation. The results of the simulation are validated with the experiments data available from the literature after the suitable grid and time scales are observed. The in-cylinder averaged quantities and droplet parameters are analyzed from the simulation. Similar studies are continued to understand the behavior of droplet variables and predict the performance and emissions by varying the swirl ratio and advancing the injection timing.

\section{METHODOLOGY}

A commercial CFD code STAR-CD is used to model and simulate the combustion process and emissions in a direct injection Diesel engine. The CFD simulation involves the three steps as outlined in the following sections.

\subsection{GRID GENERATION, GRID INDEPENDENCE AND TIME INDEPENDENCE STUDIES}

The geometry of the piston bowl is obtained from Colin et al (2003). The piston bowl shape is prepared from a standard computeraided-design package. After the piston bowl is generated, a spline is created from the bowl profile and used for the creation of in-cylinder mesh. The meshing of the in-cylinder fluid domain is performed using es-ICE (Expert System - Internal Combustion Engine) grid generation tool. In this study, a $45^{\circ}$ sector mesh is considered due to symmetry nature of the in-cylinder domain and thereby the computational time can be reduced considerably. The in-cylinder grid thus obtained is checked for negative volumes at all locations between BDC and TDC. The meshed geometry of the moving fluid domain at $40^{\circ}$ after TDC i.e. 760 deg CA is shown in Fig. 1.

The boundary of the domain consists of moving wall at the bottom, periodic zones at the sides, cylinder wall at the end side, cylinder head wall at the top, axis and the injector. Hexahedral cells are created in the in-cylinder fluid domain and a few tetrahedral cells near the fuel injector.

The hexahedral meshes are placed very fine to the wall and thereby both the hydrodynamic boundary layer and thermal boundary layers are captured more precisely. The total number of cells in the moving domain amounts to 45,000 at TDC. This cell count is verified after carrying out a series of grid independent tests as shown in Fig. 2. It can be observed from Fig. 2 that increasing the cells beyond 45000 cells does not alter the in-cylinder peak pressure and other process variables. Thus the numerical simulations are grid independent beyond 45000 cells at TDC location. Time independent study is carried out by varying the time step from $0.5 \mathrm{deg}$ CA to $0.02 \mathrm{deg} \mathrm{CA}$ as shown by logarithmic scale in Fig. 2. It can be observed that in-cylinder averaged peak pressure does not get varied even the crank angle step interval is reduced below $0.025 \mathrm{deg}$. Hence the optimum crank angle step interval is maintained at $0.025 \mathrm{deg}$ for all simulations in this study.

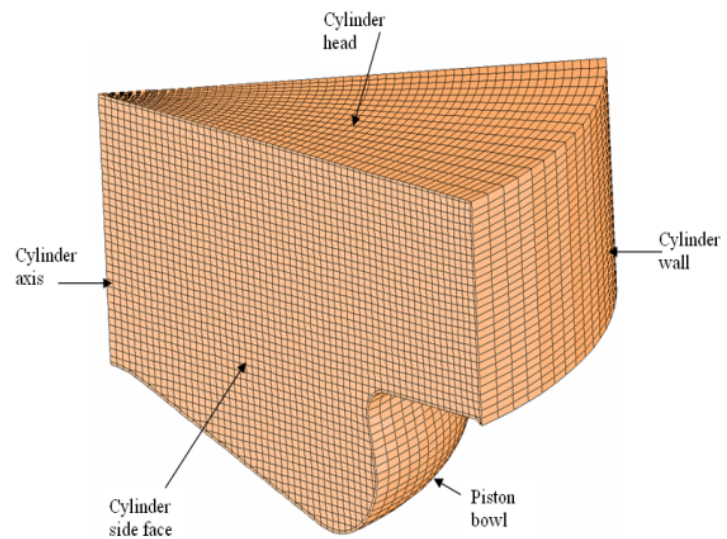

Fig. 1 Computational grid with boundary surfaces at $760 \mathrm{deg}$ CA (40 deg after TDC)

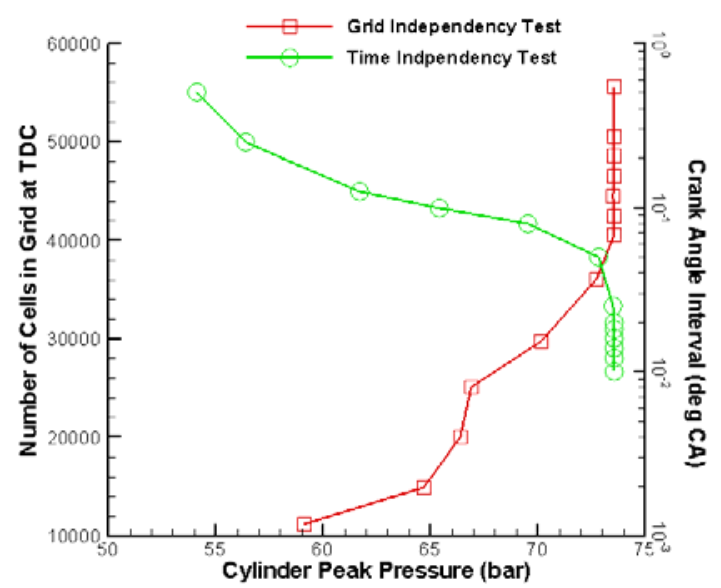

Fig. 2 Variation of peak pressure with grid density and crank angle interval

\subsection{SOLVER DETAILS}

Once the in-cylinder fluid domain mesh is available for simulation, the meshed geometry file is considered for combustion analysis in STAR-CD code. Lagrangian multiphase treatment is activated in the simulation of droplet break-up and spray penetration phenomena. The turbulent dispersion model is included for the droplet to experience randomly varying velocity field in the cylinder. Collision model (P.J. O'Rourke 1981) is also considered to detect the collision of parcels for every time step. Gravitational force is also accounted on the droplet parcels. The number of droplet parcels considered in this work is limited to 50 million which is more sufficient to capture the trajectory, spray penetration and collision physics (Munnannur 2007). RNG k- $\varepsilon$ turbulence model (Tahry 1983) is used for modeling the turbulent Eulerian flow-field in the cylinder. The flame surface density equation is solved by adopting extended coherent flame model for 3 zones namely, the unmixed fuel zone, the mixed gases zone and the unmixed zone of air together with EGR (Colin and Benkenida 2004) .

The injections of fuel start at $714^{\circ}$ which is equal to $6^{\circ}$ before TDC. The injection of droplets at three crank angles viz. $718^{\circ} \mathrm{CA}$ to 720 deg CA are as shown in Fig. 3 (a), (b) and (c) respectively. 


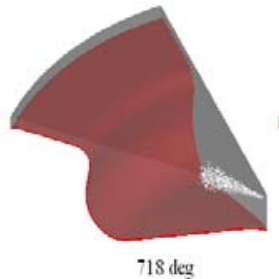

a)

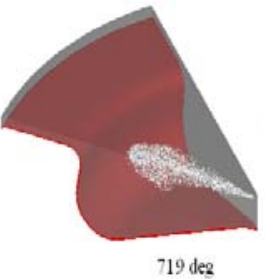

(b)

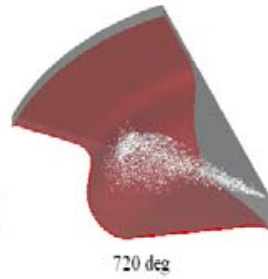

(c)
Fig. 3 Spray visualization : (a) 2 deg CA before TDC, (b) 1 deg CA before TDC and (c) at TDC

The breakup of spray as observed in Fig. 3 is common in diesel engines due to surface tension and aerodynamic shear between the fuel and surrounding air in turbulent motion inside the cylinder at high pressures.

Reitz and Diwakar (1986) spray droplet model is considered for spray formation. According to this model, break-up of droplets occur in two modes.

(a) Bag Break Up: The non-uniform pressure field in the neighborhood of droplet causes the droplet to expand in the low-pressure or wake region and eventually disintegrate when surface tension forces are overcome. This happens typically when the Weber number, $\mathrm{W}_{\mathrm{e}}>12$. The lifetime of the droplet in this mode is given as

$$
\tau_{\mathrm{b}}=\left(\pi \rho_{\mathrm{d}}^{1 / 2} \mathrm{D}_{\mathrm{d}}^{3 / 2}\right) /\left(4 \sigma_{\mathrm{d}}{ }^{1 / 2}\right)
$$

(b) Stripping Break Up: The liquid droplet is sheared or stripped from the droplet surface due to the large amplitude waves of small or large wavelengths. At high amplitudes, this is called as catastrophic break up. This mode happens typically when Weber number satisfies the condition,

$$
\mathrm{We} / \mathrm{Re}^{0.5}=0.5
$$

The lifetime of the droplet in this mode

$$
\tau_{\mathrm{b}}=\left(20 \rho_{\mathrm{d}}{ }^{1 / 2} \mathrm{D}_{\mathrm{d}}\right) /\left(2 \mathrm{u}_{\mathrm{rel}} \rho_{\mathrm{g}}{ }^{1 / 2}\right)
$$

Spray impingement model is formulated within the framework of the Lagrangian approach to reflect the stochastic nature of the impingement process. A random procedure is adopted to determine the droplet post-impingement quantities. This allows secondary droplets resulting from a primary droplet splash to have a droplet size and droplet velocity distributions.

Table 1 lists the boundary conditions applied to the in-cylinder fluid domain. The STAR-CD (CD Adapco, 2010) code computes by discretizing the fluid domain using finite volume approach under implicit formulation mode. The PISO algorithm (Pressure Implicit by Splitting of operators) is used to provide pressure velocity coupling to compute the flow-field and other transport equations. Second order upwind discretization schemes are chosen for computing the conservation equations of mass, momentum and energy.

Table 1 Boundary Conditions

\begin{tabular}{ccc}
\hline Boundary & $\begin{array}{c}\text { Momentum boundary } \\
\text { condition }\end{array}$ & $\begin{array}{c}\text { Thermal boundary } \\
\text { Condition }\end{array}$ \\
\hline Cylinder head & Wall & $450 \mathrm{~K}$ \\
Cylinder wall & Wall & $400 \mathrm{~K}$ \\
Piston bowl & Moving wall & $450 \mathrm{~K}$ \\
$\begin{array}{c}\text { Cylinder side } \\
\text { face }\end{array}$ & Periodic & $450 \mathrm{~K}$ \\
\hline
\end{tabular}

The ECFM-3Z combstion model (Colin and Benkenida 2004) is chosen for the simulation of complex mechanisms like turbulent mixing, flame propagation, diffusion combustion and pollutant formations. A small amount of exhaust gas is mixed with fresh air and then introduced into the combustion chamber. This modifies the fuel/air ratio and lowers the peak temperature so that the chemical reaction rate between nitrogen and any unused oxygen is strongly reduced. Species concentrations involved in combustion reactions can be written as a function of mixture fraction within the presumed probability density function model of combustion.

Table 2 lists the models accompanied in the code for simulation. The liquid film model (Bai and Gosman 1996) accounts for convective transport of conserved quantities within the film and from/to the gas phase. The standard pool boiling (Rohsenow 1952) is used to model liquid film boiling, when the wall temperature exceeds the saturation temperature of the liquid as the film starts to boil when the heat flux passes from the wall to the film.

\subsection{POST-PROCESSING}

Time accurate computations are allowed till the residual values of the conservation equations of continuity, momentum and energy reach $10^{-5}$. Auxiliary equations involving the turbulence, spray models and models for combustion and soot emissions are also computed at every time step. Once a time step is completed, the code outputs the in-cylinder averaged data such as pressure, temperature, heat release rate, $\mathrm{NO}_{\mathrm{x}}$ and soot emissions to an ASCII file output for further analysis. The contours of the same quantities are also obtained by storing the information at preset crank-angles.

\section{VALIDATION}

Table 3 lists the specification of engine dimensions, injection timing and combustion parameters. The $45^{\circ}$ sector CFD model of Colin and Benkenida (2004) experimental engine cylinder is modeled and a series of grid and time independency tests are carried out as shown in Fig. 2. Crank angle step interval of $0.025^{\circ} \mathrm{CA}$ (i.e. $4.167 \times 10^{-6}$ seconds) and mesh with 45000 cells at TDC position are obtained as key information for further simulation from these tests. Validation of the current simulation work is carried out with the experimental pressure data of Colin and Benkenida (2004) from the literature.

Figure 4 shows the comparison of the simulation results with the experimental in-cylinder pressure under firing conditions. The computed in-cylinder pressure data from numerical simulation are in good agreement with the experimental data. The in-cylinder averaged pressure during the non-firing mode of simulation is also shown in Fig. 4. The numerically simulated pressure values are in close agreement with the experimental data and the maximum deviation in peak pressure is less than $0.2 \%$.

Table 2 Models accompanied in code

\begin{tabular}{ll}
\hline Phenomena & Model \\
\hline Droplet breakup & Reitz-Diwakar (1986) \\
Turbulence & RNG k-E model (Tahry 1983) \\
Combustion & ECFM-3Z (Colin and Benkenida \\
Liquid Film & Angelberger et al (1997) \\
Droplet wall & Bai and Gosman (1996) \\
interaction & Huh (1991) \\
Atomization & Rohsenow (1952) \\
Boiling & Hand (1989), De Soete (1975) \\
NO $x$ mechanism & Mauss (2006) \\
Soot &
\end{tabular}


Table 3 Engine specification

\begin{tabular}{ll}
\hline Bore & $0.085 \mathrm{~m}$ \\
Stroke & $0.088 \mathrm{~m}$ \\
Compression ratio & 18 \\
Connecting Rod Length & $0.145 \mathrm{~m}$ \\
Valves/Cylinder & 4 \\
Engine Speed (N) & $1640 \mathrm{RPM}$ \\
Fuel & $\mathrm{n}$-Dodecane \\
Start of injection (deg bTDC) & 6.0 \\
Injection duration (deg.) & 8.03 \\
Injected mass (g) & 0.0144 \\
F/A equivalence ratio & 0.67 \\
EGR rate (\%) & 31 \\
Swirl ratio (SR) & 2.8 \\
Injector hole diameter & $148 \times 10^{-6} \mathrm{~m}$ \\
Spray angle & $152 \mathrm{deg}$ \\
Intake valve opening (lift at $0.5 \mathrm{~mm}$ ) & $360 \mathrm{deg}$ (TDC) \\
Intake valve closing (lift at $0.5 \mathrm{~mm})$ & $54 \mathrm{deg}$ \\
Exhaust valve opening (lift at $0.5 \mathrm{~mm}$ ) & $860 \mathrm{deg}$ \\
\hline
\end{tabular}

\section{RESULTS AND DISCUSSION}

The parameters such as in-cylinder temperature, heat release rate, $\mathrm{NO}_{\mathrm{x}}$ and soot emissions are predicted numerically for the same geometry of Beard and Colin (2003). The in-cylinder temperature increases till 736 deg CA due to diffusion combustion and thereafter decreases as expected. It is found that the peak temperature during the simulation reaches nearly $1700 \mathrm{~K}$ at nearly $740^{\circ} \mathrm{CA}$.

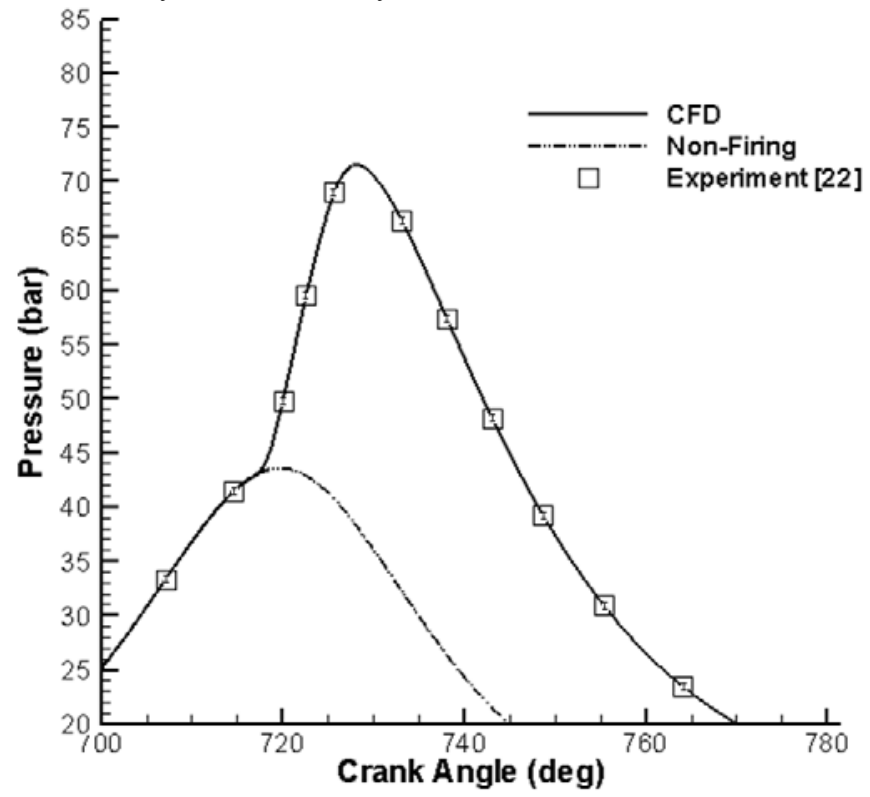

Fig. 4 Comparison of computed and experimental pressures with crank angle

The in-cylinder heat release rate curve rises after 716 deg CA steeply due to the rapid rise in pressure. During this period, the mixture may be homogeneous such that premixed combustion can happen. Due to the sudden rise in pressure, the firing inside the cylinder leads to uncontrolled combustion. After the peak heat release, the combustion is controlled due to diffusion between air and fuel particles.

The soot level rises up earlier than $720 \mathrm{deg} \mathrm{CA}$ while $\mathrm{NO}_{\mathrm{x}}$ emissions rise little later than $720 \mathrm{deg} \mathrm{CA}$. The $\mathrm{NO}_{\mathrm{x}}$ emissions are found to be higher than soot emissions. Nitrogen oxides are strongly dependent on temperature (primary dependence), oxygen concentration and duration of combustion. $\mathrm{NO}_{\mathrm{x}}$ is mainly formed during the diffusion rather than the premixed phase of combustion. Soot is formed from unburned fuel that nucleates from the vapor phase to a solid phase in fuel-rich regions at elevated temperatures. Hydrocarbons or other available molecules may condense on, or be absorbed by soot depending on the surrounding conditions.

The numerical tool thus employed here, is able to predict the various engine parameters like engine temperature, heat release rate and emissions for every degree of crank angle. This study mainly concentrates on the effect of fuel droplet mass distribution, droplet diameter and spray penetration which includes physical processes like atomization, mixing, evaporation and boiling phenomena, which are very cumbersome to measure and record experimentally. The fuel droplet traces a nearly linear path from the time of formation, often breaking and coalescing with other drops in the neighbourhood. The coalescence is however not applicable to the drops on the outer envelope of spray because the droplets are formed first and hence do not interact with other droplets on the outside. The trajectory and breakup of droplet depends on ambient pressure, neighbourhood velocity too. Break-up of these drops is negligible if the drops are small as in highpressure sprays. Thus, the droplets on the spray surface can be said to reduce in size only by vaporisation.

Evaporation of fuel depends on the temperature and relative velocity between droplet and continuous phase medium. The aerodynamic forces on a droplet depend on droplet mass. As a result, smaller droplets undergo more rapid acceleration than larger droplets. Heating times and vaporization times will be shorter for smaller droplets. The liquid sheet disintegration or atomization typically results in liquid ligaments or droplets with a characteristic dimension that is smaller than the original length scale associated with the stream. Disintegration will continue in a cascade fashion until the decreased length scale brings the Weber number for the resulting droplets below the critical value for the droplets. From the start of injection to the combustion period considered in this study, it can be observed that the droplet mass and diameter increase initially due to coalescence and later the break-up involves the mass of the droplet to decrease later $720 \mathrm{deg}$ CA. The Sauter mean diameter of the drops decreases as a consequence of increasing aerodynamic interactions (increasing the relative velocity) between liquid fuel ligaments or bigger drops and the surrounding fluid medium. The increase in SMD at short peaks may be due to rise in ambient pressure in cylinder.

The peak droplet temperature is obtained nearly a few degrees of CA after TDC due to heat transfer from the surrounding fluid medium. The droplet temperature lowers thereafter due to evaporation and heat transfer from the droplet to surrounding medium. Droplet velocity is maximum at $3 \mathrm{deg}$ before TDC. Higher droplet velocities assist the droplet to reach the end of bowl and also help in shearing or breakup of droplets. This results in greater penetration of fuel in the bowl. Droplet velocity increases initially due to higher momentum and later decreases because of the rise in in-cylinder pressure. The fluctuations in velocity and spray penetration are attributed to the turbulent nature of flow-field in the in-cylinder volume. The numerical simulation is able to predict the fuel spray characteristics, droplet diameter which is very cumbersome to measure by experimental techniques for every degree of crank angle rotation. Thus numerical study of in-cylinder engine characteristics provides a better understanding of actual physical process involved in spray distribution, mixing and combustion processes.

\section{PARAMETRIC STUDIES}

As the studies on droplet parameters gave fruitful information on the combustion and emission characteristics, the study is continued further to understand the flow physics and combustion phenomena in the cylinder by varying the swirl ratio and injection timing. For both of these cases, the engine dimensions and boundary conditions are considered to be same as in Table 3 . The swirl ratio is varied from 1.4 to 4.1 and injection timing is varied between $6 \mathrm{deg}$ bTDC to $20 \mathrm{deg}$ bTDC. 


\subsection{EFFECT OF THE SWIRL RATIO (SR)}

The swirl inside the cylinder is varied by changing the piston bowl profile as listed in the literature (Prasad et al 2011, Colin and Benkenida 2004). The bowl shape is carefully chosen (Beard and Colin 2003) to obtain the desired swirl ratio. Five cases of piston bowl are created and swirl ratio is varied as 1.4, 2.3, 3.2, 4.1 and 4.5. The swirl ratio reported here, is computed to be the highest at the end of compression stroke. Swirl enhances the mixing of air and fuel in the cylinder and therefore the combustion efficiency can be increased further. As swirl ratio is increased in the engine cylinder, the in-cylinder pressure and temperature are increased due to better fuel mixing with surrounding air and better combustion with higher heat release rates. Fig. 5 shows the peak in-cylinder average pressure rises from 73 bar to 81 bar as swirl ratio is increased from 1.4 to 4.1 . However, the peak pressure falls to 76 bar when the swirl ratio is further increased to 4.5 . The in-cylinder turbulence can be increased at higher swirl ratio of 4.5 and this leads to decrease in the cylinder temperature. As the peak pressure is highest at a swirl ratio of 4.1 amongst the cases considered, the in-cylinder and droplet variables are compared between swirl ratios of 1.4 to 4.1. The timing of maximum pressure or peak pressure inside the cylinder occurs nearly at $727 \mathrm{deg} \mathrm{CA}$. The peak in-cylinder averaged temperature increases

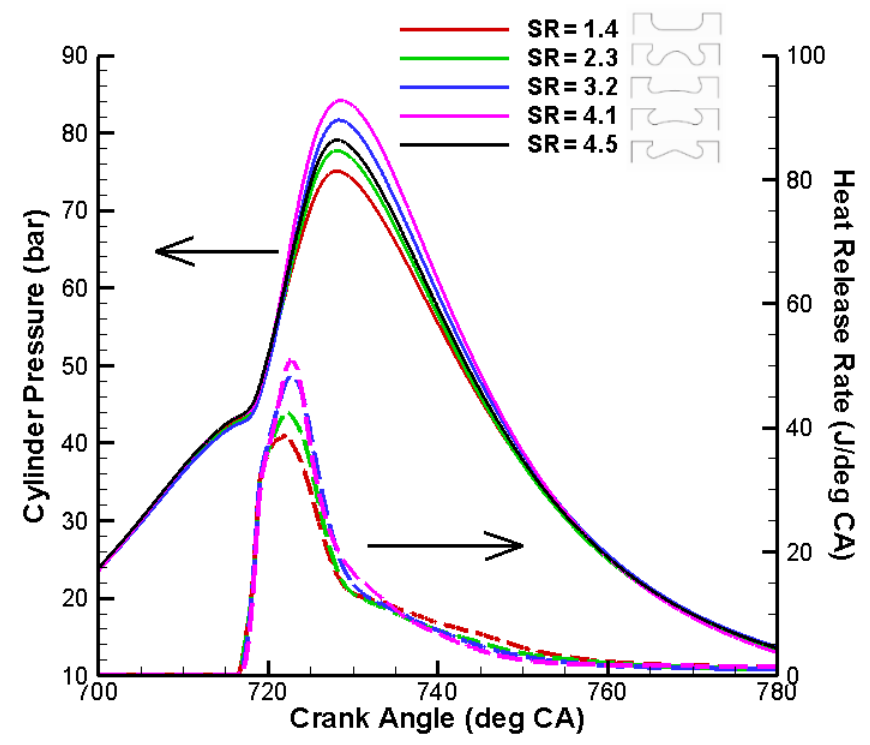

Fig. 5 Variation of pressure and heat release rate with crank angle for different swirl ratio

The heat release rates for increasing swirl ratio are also plotted in Fig. 5. It can be understood that there is $37 \%$ increase in heat release rate when swirl ratio is increased from 1.4 to 4.1 . Table 4 shows ignition delay is higher at lower swirl ratio.

Table 4 Ignition delay for various swirl ratios

\begin{tabular}{cc}
\hline Swirl Ratio & Ignition Delay (deg) \\
\hline 1.4 & 4.650 \\
2.3 & 4.225 \\
3.2 & 3.750 \\
4.1 & 3.275 \\
4.5 & 3.125 \\
\hline
\end{tabular}

from $1667 \mathrm{~K}$ to $1808 \mathrm{~K}$ when swirl ratio is increased from 1.4 to 4.1 . The ratio of change in temperature and pressure between swirl ratio matches nearly with the literature (Prasad et al 2011). The in-cylinder temperature increases with the swirl ratio.
It is also to be considered that higher swirl ratio leads to lower ignition delay in both the models due to reduced physical delay period. Ignition delay period is calculated as the difference between the start of injection timing and the start of auto-ignition for every simulation case. Although the ignition delay is lowered, the presence of better re-entrant piston bowl geometry (to account for higher swirl ratio) leads to better mixing of fuel with air followed by combustion and thereby heat release is maximum for swirl ratio of 4.1. The cumulative heat release is computed and increases with swirl ratio as $589.91 \mathrm{~J}, 603.64 \mathrm{~J}, 621.79 \mathrm{~J}$, and $625.84 \mathrm{~J}$ for swirl ratios of $1.4,2.3,3.2$ and 4.1 respectively.

The $\mathrm{NO}_{\mathrm{x}}$ emissions are compared for various swirl ratio as shown in Fig. 6. Since the temperature in the cylinder increases with the swirl ratio, the $\mathrm{NO}_{\mathrm{x}}$ emission levels are also observed to be higher. As swirl ratio increases from 1.4 to 4.1 , the $\mathrm{NO}_{\mathrm{x}}$ levels increases from 4.4 $\mathrm{g} / \mathrm{kg}$ of fuel to $8.6 \mathrm{~g} / \mathrm{kg}$ of fuel respectively. The soot emissions exhibit reverse trend with the $\mathrm{NO}_{\mathrm{x}}$ emissions as in Fig. 6. The soot levels decrease with the increase in swirl ratio from 1.4 to 4.1 due to better mixing of fuel and air, leading to lower fuel accumulation and deposition. Although the soot levels increases with time, the overall soot level reduction is $21 \%$ from swirl ratio of 1.4 to 4.1 .

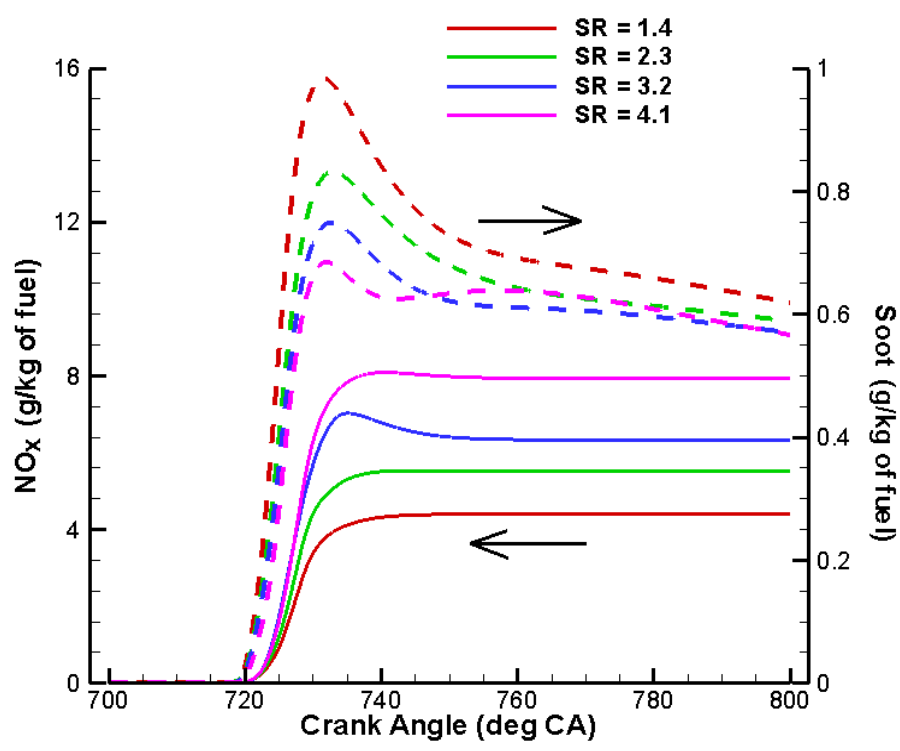

Fig. 6 Variation of $\mathrm{NO}_{x}$, soot for different swirl ratio

The droplet parameters are studied by considering the increase in swirl ratio from 1.4 to 4.1 . The increase in swirl ratio leads to the additional break-up of droplets and interaction between the surrounding air and droplet is increased at higher swirl ratio. This leads to the breakup of droplets due to shear. As the droplet break up continues till the start of combustion, the resulting droplets that are not involved in primary combustion exhibit a relative change in diameter of the droplet after $725 \mathrm{deg}$ CA. Evaporation is followed by final stage of droplet break up, leading to the reduction of droplet mass. Sauter mean diameter increases for swirl ratios of 3.2 and 4.1 twice as compared to swirl ratios of 1.4 and 2.3 due to the chance of coalescence at higher swirl ratio as shown in Fig. 7.

The reason for lower SMD for swirl ratios of 3.2 and 4.1 is due to the higher relative velocity caused by the swirl ratio for 3.2 and 4.1 , the droplet SMD gets affected in the same time period. The SMD falls once the diffusion combustion initiates.

The droplet temperature is observed to be highest for swirl ratio of 4.1 as shown in Fig. 7. This is due to the higher in-cylinder temperature at highest swirl ratio of 4.1. Heat transfer from surrounding air to the droplet is significant at higher in-cylinder temperatures for the swirl ratio of 4.1. From the computations, it is observed that the spray 
penetration becomes insignificant as the ambient gas pressure increases. As the ambient gas pressure increases the pressure drop across the nozzle decreases and so the spray penetration also decreases.

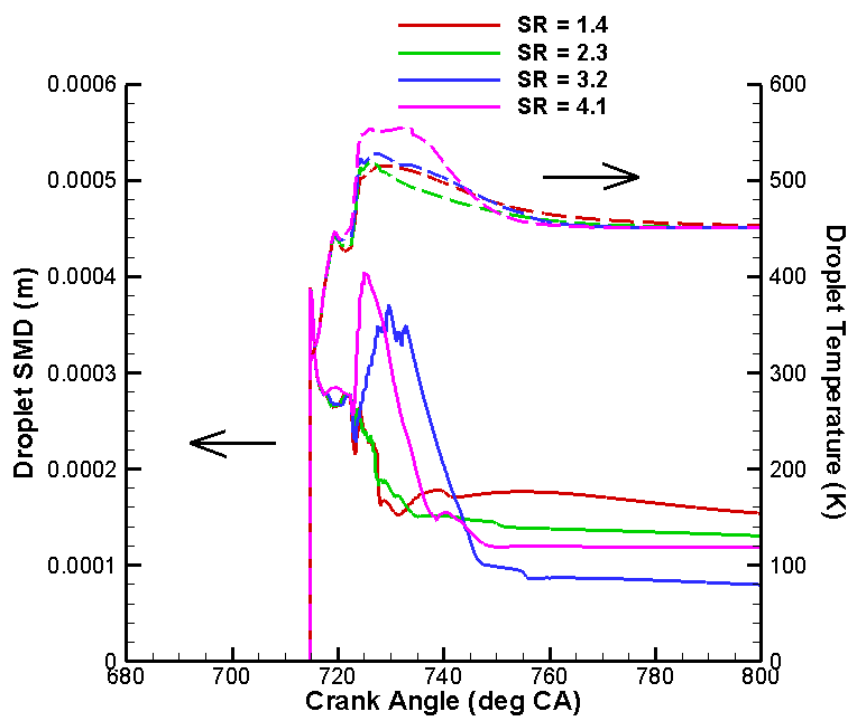

Fig. 7 Variation of droplet SMD and droplet temperature for different swirl ratio

\subsection{EFFECT OF THE INJECTION TIMING (IT)}

The effect of variation in injection timing is carried out numerically with the optimized swirl ratio of 4.1. The injection timings considered are 6 deg before TDC (or) $714 \mathrm{deg}$ CA, $13 \mathrm{deg}$ bTDC (or) $707 \mathrm{deg}$ CA,20 deg bTDC (or) $700 \mathrm{deg}$ CA and $27 \mathrm{deg}$ bTDC (or) $693 \mathrm{deg}$ CA.

The in-cylinder averaged pressure is shown in Fig. 8 for different injection timing. The delay period for every case of injection timing are given in Table 5 .

Table 5 Delay period for different injection timings

\begin{tabular}{cc}
\hline $\begin{array}{c}\text { Injection } \\
\text { Timing (deg } \\
\text { CA) }\end{array}$ & $\begin{array}{c}\text { Delay Period } \\
\text { (deg CA) }\end{array}$ \\
\hline 714 & 3.275 \\
707 & 6.150 \\
700 & 7.275 \\
693 & 8.125 \\
\hline
\end{tabular}

Advancing the injection timing with respect to TDC results in increase in the cylinder pressure due to increased delay period. The incylinder pressure and temperature is higher for the case when the time of start of injection is $20 \mathrm{deg}$ bTDC as compared to the case of $6 \mathrm{deg}$ bTDC. This leads to a $15 \%$ increase in cylinder pressure from injection timing of 6 deg bTDC to 20 deg bTDC. These numerically simulated values are in good agreement with Jayashankara and Ganesan (2010). The delay period is almost doubled when the injection timing is varied from $6 \mathrm{deg}$ bTDC to $13 \mathrm{deg}$ bTDC, resulting in increase of peak cylinder pressure from 81 bar to 89 bar. However, the peak pressure falls to 86 bar as injection timing is ther advanced to 693 deg CA i.e. 27 deg bTDC. This is because the in-cylinder temperature might not be sufficient at $693 \mathrm{deg} \mathrm{CA}$ for the fuel-air mixture to attain auto-ignition and thereby leads to a slightly lower peak pressure. Hence, the incylinder and droplet variables are compared between 6 to 20 deg bTDC injection timings. As in-cylinder peak pressure is higher with injection timing of $20 \mathrm{deg}$ bTDC, the in-cylinder peak temperature is also higher at the same injection timing. It is observed that there is an increase in cylinder temperature with the advancement of injection timing till 700 $\operatorname{deg} \mathrm{CA}$ and thereafter the temperature decreases.

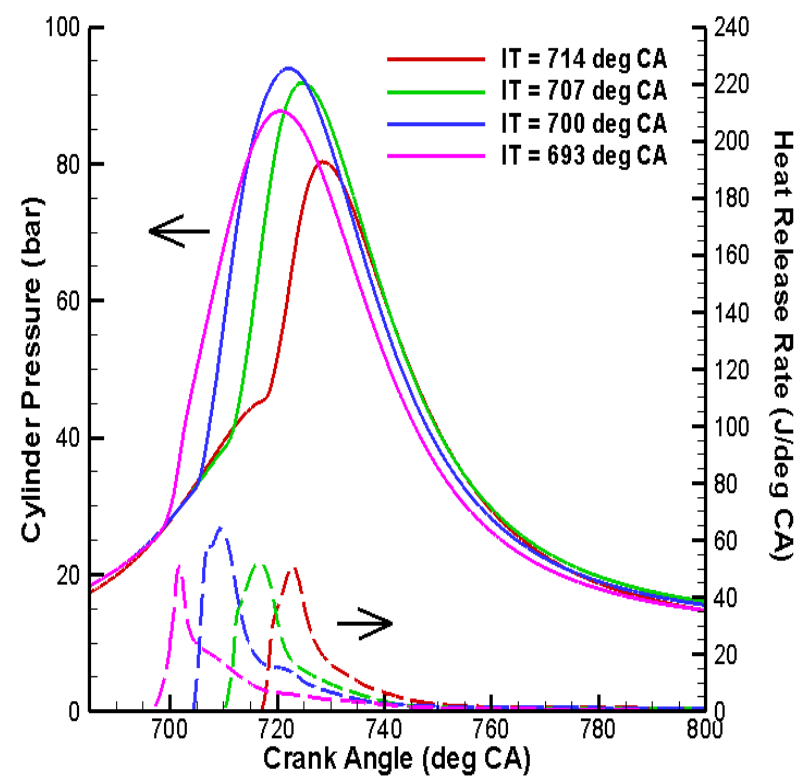

Fig. 8 Computed pressure, heat release rate with crank angle for different injection timings

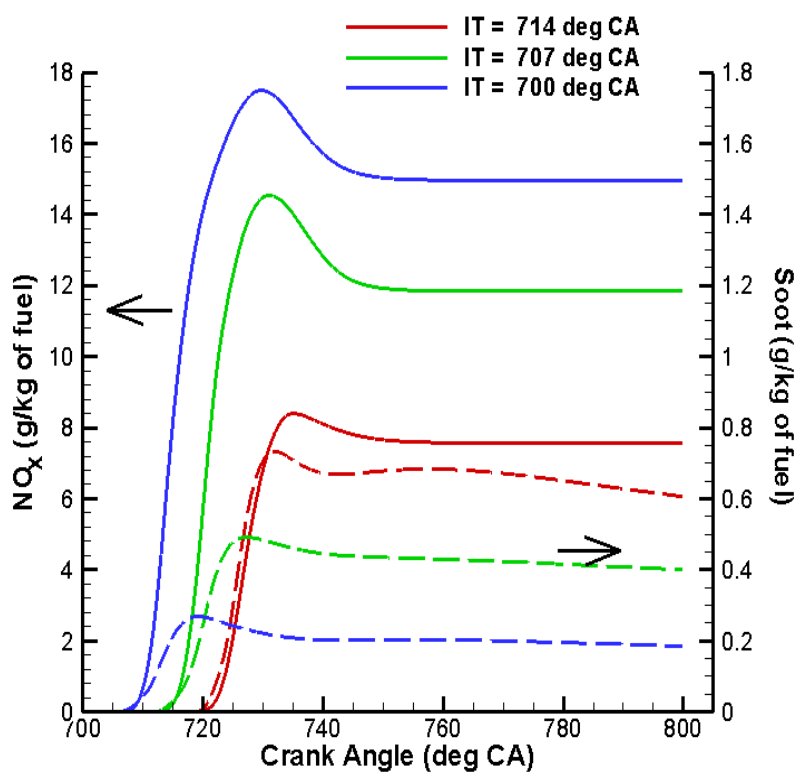

Fig. 9 Computed $\mathrm{NO}_{\mathrm{x}}$, soot for different injection timings

The ignition delay period is longer as the injection timing is advanced since the required in-cylinder pressure and temperature are not sufficient to start the auto-ignition process. The delay period is listed against the injection timing in Table. 5. The heat release rates at three injection timings are also shown in Fig. 8. The peak heat release rate is observed to be highest with injection timing of 700 deg CA than the remaining cases. The slope of the rising curve is highest at injection timing of $700 \mathrm{deg} \mathrm{CA}$, and thereby the heat release rate is rapid during this uncontrolled combustion period. The cumulative heat release increases with advancing the injection timing. These values are found to be $625.84 \mathrm{~J}, 667.61 \mathrm{~J}$ and $687.83 \mathrm{~J}$ at injection timings of $714 \mathrm{deg} \mathrm{CA}$, 707 deg CA and 700 deg CA respectively.

The $\mathrm{NO}_{\mathrm{x}}$ and soot emissions are shown in Fig. 9. As the incylinder temperature is higher at injection timing of $700 \mathrm{deg} \mathrm{CA}$, the $\mathrm{NO}_{\mathrm{x}}$ emissions are higher for the same case. It is observed that the $\mathrm{NO}_{\mathrm{x}}$ levels increases nearly twice between the injection timing of $714 \mathrm{deg}$ 
CA and 700 deg CA respectively. The soot levels are observed to decrease with the advance in injection timing due to reduction in droplet diameter and longer ignition delay period. The soot levels decreases nearly by one-third when the injection timing is advanced to $700 \mathrm{deg}$ CA from $714 \mathrm{deg}$ CA. The variation of soot emissions as observed in Fig. 9 are in correspondence with the droplet diameter of Fig. 10.

The droplet mass and droplet diameter increases with advancement of injection timing. Due to the increase in delay period with the advance in injection timing, the droplet undergoes break-up to a greater extent and hence overall mass of the droplet can be lowered as compared to the other injection timings considered. The same trend is observed with the droplet SMD, whereas another rise in peak occurs for later injection timing. This is because the relative velocity between the fuel droplet and surrounding air is lower. This is verified by observing the droplet velocity variation after the computations. Higher droplet velocities are obtained for an injection timing of $20 \mathrm{deg}$ CA bTDC (or) $700 \mathrm{deg}$ CA. This is due to lower in-cylinder pressure at the time of injection and thereby higher drag force is experienced by the droplet as compared to other injection timings.

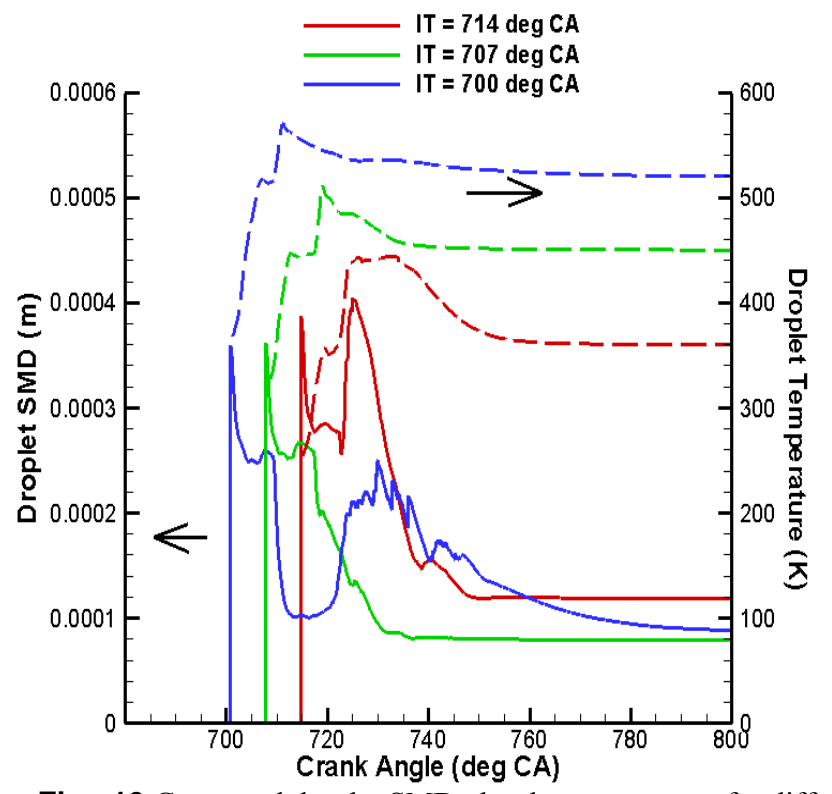

Fig. 10 Computed droplet SMD, droplet temperature for different injection timing

The droplet temperature is observed to be maximum when the injection timing is advanced as shown in Fig. 10. This is due to higher in-cylinder temperature during combustion, caused by longer delay period. Heat transfer due to combustion increases the droplet temperature further. The spray penetration is affected by the in-cylinder pressure as discussed earlier and the spray penetration is maximum with higher injection angle of $700 \mathrm{deg}$ CA or $20 \mathrm{deg}$ CA bTDC. This is because the resistance offered by air pressure inside the cylinder is reduced when the injection timing is advanced.

\section{CONCLUSIONS}

In the present work, different models governing the direct injection diesel engine combustion and pollutant formation are studied. Grid and time independent tests are carried out and the results are validated with the literature experimental data. In-cylinder flow-field, temperature and heat release rate are investigated. The variation of droplet parameters such as droplet mass, droplet diameter, droplet velocity, droplet temperature and spray penetration are also studied, however few are reported here. The analyses are extended towards understanding the droplet behavior, combustion and pollutant formation by varying the in- cylinder swirl ratio and injection timing. From the results, the following conclusions are obtained.

1. When the swirl ratio is increased from 1.4 to 4.1 , the peak incylinder pressure increases by 8 bar thereby resulting in better combustion. The peak pressure falls by 5 bar as swirl ratio is increased beyond 4.1 .

2. Heat release rate occurs nearly at $722 \mathrm{deg}$ CA and increases by $37 \%$ when swirl ratio is increased from 1.4 to 4.1 .

3. Due to higher temperature the $\mathrm{NO}_{\mathrm{x}}$ emissions are doubled, while soot emissions are halved when the swirl ratio is increased to 4.1 from 1.4. Decrease in soot levels occur at lower Sauter Mean Diameter.

4. Advancing the injection timing leads to increase in in-cylinder averaged quantities like pressure and temperature considerably. The pressure rise is $15 \%$ over the injection timing advancement of $14 \mathrm{deg}$ CA. This is due to longer ignition delay period as the in-cylinder pressure and temperature is not sufficient at the end of compression stroke for the fuel-air mixture to attain auto-ignition. There is a decrease in peak pressure and heat release rate when the injection timing is advanced to $27 \mathrm{deg}$ bTDC.

5. Heat release increases by $40 \%$ by advancing the injection timing from $714 \mathrm{deg}$ CA to $700 \mathrm{deg}$ CA. This results in better combustion due to prolonged combustion period and ignition delay period.

6. Nitrogen oxides and soot emissions show inversing trend with the advancement of injection timing. $\mathrm{NO}_{\mathrm{x}}$ levels are doubled and soot emissions are decreased by one-third from $714 \mathrm{deg}$ CA to 700 deg CA.

7. Droplet parameters are studied and found to affect the combustion process and emission formation significantly by varying the swirl ratio and injection timings.

\section{NOMENCLATURE}

$\begin{array}{ll}\text { bTDC } & \text { before Top Dead Centre } \\ \text { BDC } & \text { Bottom Dead Centre } \\ \text { CA } & \text { Crank Angle } \\ \text { CFD } & \text { Computational Fluid Dynamics } \\ \text { D } & \text { Diameter } \\ \text { HC } & \text { Hydrocarbons } \\ \text { IT } & \text { Injection timing } \\ \text { J } & \text { Joule } \\ \text { k } & \text { Turbulent kinetic energy } \\ \mathrm{NO}_{x} & \text { Oxides of nitrogen } \\ \text { SR } & \text { Swirl ratio } \\ \text { SMD } & \text { Sauter Mean Diameter } \\ \text { T } & \text { Break-up time } \\ \text { TDC } & \text { Top Dead Centre } \\ \text { u } & \text { Velocity }\end{array}$

\section{Greek symbols}

$\varepsilon \quad$ Turbulent eddy dissipation rate

$\mu \quad$ Dynamic viscosity

$\rho \quad$ Density

$\sigma \quad$ Surface tension

$\tau \quad$ Life time

\section{Suffixes}

b breakup

d droplet

g gas phase (Eulerian)

rel relative 


\section{REFERENCES}

Heywood J. B., 1988, Internal Combustion Engine Fundamentals, McGraw-Hill, New York, 491-566.

Reitz R.D., Diwakar R., 1986, "Effect of Drop Breakup on Fuel Sprays," SAE Technical Paper Series 860469.

http://dx.doi.org/10.4271/860469

Magnussen B.F., Hjertager B.H., 1976, “'On Mathematical Modeling of Turbulent Combustion with Special Emphasis on Soot Formation and Combustion," 16th Symp. on Combustion, The Combustion Institute, 719-729.

http://dx.doi.org/10.1016/S0082-0784(77)80366-4

Hossainpour S., Binesh A.R., 2009, "Investigation of fuel Spray Atomization in a DI Heavy-Duty Diesel Engine and Comparison of Various Spray Breakup Models," Fuel 88, 799-805.

http://dx.doi.org/10.1016/j.fuel.2008.10.036

Prasad B.V.V.S.U., Sharma C.S., Anand T.N.C., Ravikrishna R.V., 2011, "High Swirl-inducing Piston Bowls in Small Diesel Engines for Emission Reduction," Applied Energy 88, 2355-2367.

http://dx.doi.org/10.1016/j.apenergy.2010.12.068

Arcoumanis C., Gavaises M., French B., 1997, "Effect of Fuel Injection On The Structure Of Diesel Sprays," SAE Paper 970799.

http://dx.doi.org/10.4271/970799

Rakopoulos C.D., Kosmadakis G.M., Pariotis E.G., 2010, "Investigation of Piston Bowl Geometry and Speed Effects in a Motored HSDI Diesel Engine Using A CFD Against a QuasiDimensional Model," Energy Conversion and Management 51-3, 470484.

http://dx.doi.org/10.1016/j.enconman.2009.10.010

Kar M.P., Hoon K.N., Gan S., 2012, "Simulation of Temporal and Spatial Soot Evolution in an Automotive Diesel Engine Using the Moss-Brookes Soot Model," Energy Conversion and Management 58, 171-184.

http://dx.doi.org/10.1016/j.enconman.2012.01.015

Torregrosa A.J., Bermúdez V., Olmeda P., Fygueroa O., 2012, "Experimental Assessment for Instantaneous Temperature and Heat Flux Measurements under Diesel Motored Engine Conditions," Energy Conversion and Management 54-1, 57-66.

http://dx.doi.org/10.1016/j.enconman.2011.10.009

Thurnheer T., Edenhauser D., Soltic P., Schreiber D., Kirchen P., Sankowski A.,2011, "Experimental Investigation On Different Injection Strategies in A Heavy-Duty Diesel Engine: Emissions and Loss Analysis," Energy Conversion and Management 52-1, 457-467. http://dx.doi.org/10.1016/j.enconman.2010.06.074

Costa M., Sorge U., Allocca L., 2012, "Increasing Energy Efficiency of a Gasoline Direct Injection Engine Through Optimal Synchronization of Single or Double Injection Strategies," Energy Conversion and Management 60 , 77-86.

http://dx.doi.org/10.1016/j.enconman.2011.12.025

Chmela F.G., Pirker G.H., Wimmer A., 2007, "Zero-Dimensional ROHR Simulation for DI Diesel Engines - A Generic Approach," Energy Conversion and Management 48(11), 2942-2950.

http://dx.doi.org/10.1016/j.enconman.2007.07.004
Catania A.E., Finesso R., Spessa E., 2011, "Predictive ZeroDimensional Combustion Model for DI Diesel Engine Feed-Forward Control," Energy Conversion and Management 52(10), 3159-3175. http://dx.doi.org/10.1016/j.enconman.2011.05.003

Kondoh T., Fukumoto A., Ohsawa K., Ohkubo Y., 1985, "An Assessment of a Multidimensional Numerical Method to Predict the Flow in Internal Combustion Engines," SAE Paper 850500.

http://dx.doi.org/10.4271/850500

Cenk Sayin, Mustafa Canakci, 2009, "Effects of Injection Timing on the Engine Performance and Exhaust Emissions of A Dual-Fuel Diesel Engine," Energy Conversion and Management, 50, 203-213. http://dx.doi.org/10.1016/j.enconman.2008.06.007

Han Z., Uludogan A., Hampson G.J., Reitz R.D., 1996, "Mechanism of Soot and $\mathrm{NO}_{\mathrm{X}}$ Emission Reduction Using Multiple-Injection in a Diesel Engine," SAE paper no. 960633.

http://dx.doi.org/10.4271/960633

Jayashankara B., Ganesan V., 2010, "Effect of Fuel Injection Timing and Intake Pressure on the Performance of A DI Diesel Engine - A Parametric Study Using CFD," Energy Conversion and Management 51, 1835-1848.

http://dx.doi.org/10.1016/j.enconman.2009.11.006

Payri F., Benajes J., Margot X., Gil A., 2004, "CFD Modeling of the InCylinder Flow in Direct-Injection Diesel Engines," Computers and Fluids 33, 995-1021.

http://dx.doi.org/10.1016/j.compfluid.2003.09.003

Béard P., Colin O., Miche M., 2003, "Improved Modeling of DI Diesel Engines Using Sub-Grid Descriptions of Spray and Combustion," SAE Paper 2003-01-0008.

http://dx.doi.org/10.4271/2003-01-0008

O”Rourke P.J., 1981, “Collective Drop Effects on Vaporising Liquid Sprays," PhD Thesis, University of Princeton.

Munnannur A, 2007, "Droplet Collision Modeling in MultiDimensional Engine Spray Computations," Ph.D. Dissertation, University of Wisconsin-Madison.

El Tahry S.H., 1983, "k- $\varepsilon$ Equation for Compressible Reciprocating Engine Flows," AIAA J. Energy 7, 345-353.

http://dx.doi.org/10.2514/3.48086

Colin O., Benkenida A., 2004, "3-Zone Extended Coherent Flame Model (ECFM3Z) for Computing Premixed/Diffusion Combustion," Oil and Gas Science and Technology - Rev. IFP, 59,593-609.

Angelberger C., Poinsot T., Delhay B., 1997, "Improving Near-Wall Combustion and Wall Heat Transfer Modeling in SI Engine Computations," SAE Technical Paper Series 972881, 113-130. http://dx.doi.org/10.4271/972881

Bai C., Gosman A.D., 1996, "Mathematical Modeling of Wall Films Formed by Impinging Sprays," SAE Technical Paper Series 960626. http://dx.doi.org/10.4271/960626

Huh K.Y., Gosman A.D., 24-27 September 1991, “A Phenomenological Model of Diesel Spray Atomisation," Proc. Int. Conf. on Multiphase Flows (ICMF “91), Tsukuba.

Rohsenow, W.M., 1952, “A Method of Correlating Heat Transfer Data for Surface Boiling Liquids," Transactions of the ASME, 74, 969. 
STAR methodology for internal combustion engine applications, 2010, CD-adapco version 4.16 .

Manimaran R., Thundil Karuppa Raj R., 2013, "Numerical Investigations on Combustion and Emission Characteristics in a Direct Injection Diesel Engine at Elevated Fuel Temperatures," Frontiers in Heat and Mass Transfer, 4, 013008.

http://dx.doi.org/10.5098/hmt.v4.1.30081871

Hand G., Missaghi M., Pourkashanian M., Williams A., 1989, "Experimental Studies and Computer Modelling of Nitrogen Oxides in a Cylindrical Natural Gas Fired Furnace," $9^{\text {th }}$ Members Conf.,
International Flame Research Foundation, Noordwijkerhout, The Netherlands .

De Soete G.G., 1975, "Overall Reaction Rates of NO and N2 Formation from Fuel Nitrogen," 15th Symp. (Int.) on Combustion, The Combustion Institute, 1093-1102.

Mauss F., Netzell K., Lehtiniemi H., 2006 "Aspects of Modeling Soot Formation in Turbulent Diffusion Flames," Combust. Sci. and Tech. 178, $1871-1885$.

http://dx.doi.org/10.1080/00102200600790888 